\title{
Characteristics of Potential Gamma-Aminobutyric Acid-Producing Bacteria Isolated from Korean and Vietnamese Fermented Fish Products
}

\author{
Thi Thu-Thao Vo and Jong-Hyun Park ${ }^{*}$
}

Department of Food Science and Biotechnology, College of BioNano Technology, Gachon University, Seongnam 13120, Republic of Korea

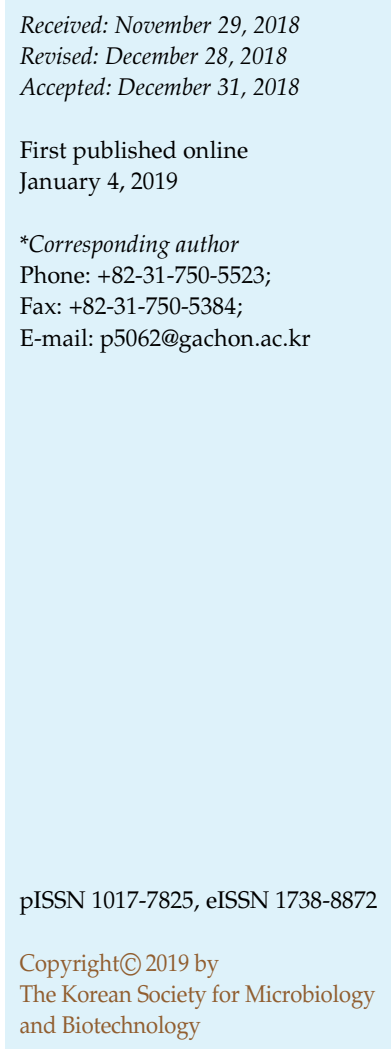

Gamma-aminobutyric acid (GABA) is a neurotransmitter that exerts several physiological functions and positive effects on human health. The aim of this study was to isolate and characterize the strains that had GABA-producing abilities from various fermented fish products. A total of 91 acid-producing strains were isolated from 41 samples of fermented fish products, and 27 strains showing GABA-producing abilities were identified by the 16S rDNA sequences. Among the strains, 31\% strains tolerated at high-salt environment of 10-20\% throughout the fermentation of fish sauces. The 27 isolates that produced GABA at various concentrations did so in the range of 5 to $454 \mathrm{mM}$. These GABA-producing isolates were identified as lactic acid bacteria of 14 strains, which included twelve Lactococcus lactis, one Enterococcus faecium, and one Lactococcus pentosus; eight Bacillus cereus group, which included seven B. thuringiensis and one B. cereus; and five Staphylococcus spp. Interestingly, with Vietnamese fish sauces, we mostly identified species of B. thuringiensis and Staphylococcus spp., while with Korean fermented fish products, the majority of the strains identified belonged to L. lactis. Among the strains, B. thuringiensis LH2134 produced the highest levels of GABA at $366 \mathrm{mM}$ among the strains identified from Vietnamese fish sauces, whereas L. lactis LA43, a new strain isolated from Korean jeotgal (salted shrimp paste), produced the highest amount of GABA at $454 \mathrm{mM}$ and the glutamate concentration in the medium was essential for GABA accumulation. Therefore, such the isolates might serve as good starters for development of more GABA-reinforced foods among fermented fish products.

Keywords: Gamma-aminobutyric acid, fermented fish products, glutamate, lactic acid bacteria, Bacillus, Staphylococcus

\section{Introduction}

Fermented fish products are valuable nutritional condiments made by combining fish and sea salt. They are generally used as a main ingredient for traditional foods in various cuisines in Asia. In Vietnam, they are called nuoc mam (fish sauce) and are one of the few traditional products manufactured on a large scale throughout the country, with an annual output of approximately 220 million products. In Korea, they are called aekjeot, and are typically used in kimchi to accelerate the fermentation process. On some occasions, they are also used in Korean side dishes and soup or stew to give extra umami (flavor).
Thus, they are considered one of the most important sources of dietary proteins. Fish sauce contains up to $20 \mathrm{~g} / 1$ nitrogen, $80 \%$ of which is in the form of essential amino acids. Glutamic acid, aspartic acid, and lysine are three amino acids mostly present in fish sauce [1], which contains particularly high amounts of glutamic acid $(23 \mathrm{mg} / \mathrm{ml})$ [2]. Glutamic acid is a precursor of gamma-aminobutyric acid (GABA), and also helps to give the characteristic flavor of fish sauce.

GABA is a four-carbon, non-protein amino acid that is widely present in bacteria, plants, and vertebrates. It is principally formed by an $\alpha$-decarboxylation reaction of L-glutamic acid or its salts, and catalyzed by glutamic acid 
decarboxylase, whose biochemical properties have been reported previously [3]. GABA is served as a bioactive compound in foods and is seen as a great bioactive natural compound for human health since it exerts several physiological functions and also has positive antioxidant, anti-diabetes, hypotensive, and anxiety reduction effects [4]. GABA could delay or inhibit the invasion and metastasis of various types of cancer cells in the mammary gland, colon, and hepatic cancer cells [5]. Indeed, GABAenriched food is required because the GABA content in the typical daily human diet is relatively low [6]. As a result, the development of functional foods containing GABA has been actively increased with a vast variety of GABAenhanced food products including cereals, sourdough, breads, cheeses, fermented sausages, teas, vegetables, legumes, dairy soy products, alcohol beverages, and especially traditional Asian fermented foods [7].

A high amount of GABA is found mainly in fermented products, especially fermented dairy products [8]. GABA produced by fermentation with microorganisms has been reported in bacteria, fungi, and yeasts [9]. The most interesting and practical group of bacteria for GABA production is lactic acid bacteria (LAB), including strains of Lactobacillus (L.), and Lactococcus (Lc.), of which L. brevis was isolated from many fermented foods such as Chinese traditional paocai [10], fresh milk [11], soya yogurt [12], and black raspberry juice [13]. The strains L. delbrueckii, L. plantarum, and L. paracasei were isolated from cheese and Japanese traditional fermented fish [14, 15], respectively. The best GABA-producing LAB strains were L. paracasei, L. delbrueckii, L. lactis, and L. brevis isolated from a variety of Italian cheeses, and Lc. lactis sp. were screened from cheese starters with the highest level of GABA production $(391 \mathrm{mg} / \mathrm{kg})$ [16]. A total of 61 GABA-producing LAB strains were identified in cheese [9]. Other GABA-producing LAB were considered as potential candidates for fermentation in skim milk [16].

For GABA producers in fermented foods in Vietnam, remarkably, three GABA-producing strains were isolated from Nem chua (sour fermented pork), and these were L. plantarum NCDC3, L. plantarum BAC52, and L. brevis NCTH24. One isolated from dua chua (sour fermented vegetables) was L. plantarum LD3, and one isolated from Com ruou (fermented white rice paste) was L. plantarum LV1. These five strains were all LAB strains, four of which belonged to $L$. plantarum and another that belonged to L. brevis [17]. Similarly in Korea, GABA-producing strains isolated from kimchi including L. brevis NCL912 [18],
Lactobacillus buchneri MS [19], and Lc. lactis. subsp. lactis B produced the highest amount of GABA (3.68 g/l) [20].

GABA-producing LAB strains have mostly been found in fermented foods including cheese, skim milk, raw milk, and yogurt as well as fermented fish products such as fish sauce. L. paracasei has been found in Japanese traditional fermented fish with strain NFRI 7415 producing GABA at a concentration of $302 \mathrm{mM}$ [15]. However, there have been few strains as GABA producers isolated from Vietnamese or Korean fermented fish products up to now.

The aim of this study was to screen various types of GABA-producing bacteria from fermented fish products in Vietnam and Korea as well as those used as possible starters in the production of fermented foods. The new GABA-producing strains were hypothesized to enhance the development of functional fermented foods containing GABA.

\section{Materials and Methods}

\section{Microbiological Analysis}

Forty-one samples of fermented fish products including 29 fish sauces, five anchovy pastes, two sour shrimp pastes, and five salted shrimp pastes were obtained from markets in Vietnam and Korea. Viable bacterial cells in fish samples were enumerated by a conventional counting method. The fish samples were homogenized in saline solution and spread-plated on plate count agarbromocresol purple (PCA-BCP) agar supplement with $2.5 \mathrm{mg} / 1$ amphotericin $\mathrm{B}$. The agar plates were incubated at $30^{\circ} \mathrm{C}$ for 2 days under anaerobic condition using BD BBL GasPak anaerobic and $\mathrm{CO}_{2}$ indicators (Becton, Dickinson and Company, USA). Colonies that formed a yellow halo were selected, and then screened on De Man, Rogosa and Sharpe (MRS) agar (Oxoid, England) for identification as acid-producing bacteria. Furthermore, isolates were harvested and purified again on MRS medium and stored frozen at $-80^{\circ} \mathrm{C}$ with $20 \%$ glycerol for further characterization [21].

\section{Phenotypic Characterization of Isolated Bacteria}

All of the isolates were initially tested for Gram reaction by the $\mathrm{KOH}$ method, while catalase reaction, gas production from glucose, and fermentative type were also determined by culture on homofermentative-heterofermentative differential (HHD) medium [22]. MRS broth was used to measure the growth at $\mathrm{pH}$ values ranging from 2 to 9 . The salt tolerance tests were carried out with MRS broth medium containing 3, 6.5, 10, 15, 20, and 25\% $\mathrm{NaCl}(\mathrm{w} / \mathrm{v})$, and the range of growth temperature was assayed at $4,10,15,37,45,50$, and 15 min-heat shock at $60^{\circ} \mathrm{C}$ in MRS broth, respectively [23]. Using these tests, the isolates were grouped based on their characteristics. 
GABA-Producing Analysis by Thin-Layer Chromatography (TLC) and High-Performance Liquid Chromatography (HPLC)

GABA production was analyzed qualitatively by the aluminum TLC silica gel plate (Aluminum Sheets Silica gel 60 F254, Merck, Germany) [24]. Cells were cultivated in MRS broth supplement with $1 \%$ monosodium glutamate (MSG) at $30^{\circ} \mathrm{C}$ for $72 \mathrm{~h}$. Culture supernatants were obtained by centrifugation at $9,000 \times g$ for $10 \mathrm{~min}$ and then subjected to TLC analysis. An $0.75-\mu \mathrm{l}$ aliquot of sample supernatant and standard at a concentration of $2 \mathrm{mg} / \mathrm{ml}$ was spotted on the TLC plate. Plates were air-dried and subjected to a TLC solvent mixture (1-butanol : acetic acid : distilled water at 5:3:2 ratio) dissolved directly with $0.4 \%(\mathrm{w} / \mathrm{v})$ ninhydrin as the mobile phase. TLC plates were developed for $2 \mathrm{~h}$, and then dried in the convection oven at $60^{\circ} \mathrm{C}$ for $15 \mathrm{~min}$ to yield a red-purple color.

The GABA production was quantified by HPLC basically following the method of Kim [25] with some modifications. Culture supernatants and GABA standard solutions were derivatized with phenylisothiocyanate (PITC) [26]. Briefly, aliquots of $500 \mu \mathrm{l}$ of culture supernatant and GABA standards were dried using a speed-vacuum concentrator (Vacuum Concentrators VC2124, Gyrozen, Korea). The residue was dissolved in $100 \mu \mathrm{l}$ mixture of ethanol-water-triethylamine $(2: 2: 1 \mathrm{v} / \mathrm{v} / \mathrm{v})$ and evaporated to dryness. An aliquot of $150 \mu \mathrm{l}$ ethanol-water-triethylamine-PITC $(7: 1: 1: 1 \mathrm{v} / \mathrm{v} / \mathrm{v} / \mathrm{v})$ was added to the residue and incubated for $20 \mathrm{~min}$ at room temperature to form phenylthiocarbamyl-GABA. The dry residue was dissolved in $500 \mu \mathrm{l}$ of the mobile phase consisting of $80 \%$ solution A $(1.4 \mathrm{mM}$ sodium acetate, $0.1 \%$ triethylamine, $6 \%$ acetonitrile) and $20 \%$ solution B (60\% acetonitrile). The solutions were filtered through $0.45 \mu \mathrm{m}$ membranes and then subjected to HPLC analysis. The GABA analysis was performed using an UltiMate 3000 Standard Dual HPLC System equipped with an Acclaim $120 \mathrm{C} 18$ column (Thermo Fisher, Korea). The column was eluted for $50 \mathrm{~min}$ with a linear gradient of $0-100 \%$ solution B at a flow rate of $1 \mathrm{ml} / \mathrm{min}$. A sample volume of $20 \mu \mathrm{l}$ was injected and monitored at a wavelength of $254 \mathrm{~nm}$. Sample peak areas were measured and compared with the calibration curve standard of GABA at known concentrations $(2.5,5,7.5$, and $10 \%$ ) in order to quantify GABA concentrations. The conversion rate of glutamate to GABA was calculated based on the produced GABA and initial glutamate content.

\section{Genetic Analysis of GABA-Producing Microorganisms}

Analyses of the $16 \mathrm{~S}$ rRNA gene sequence were performed to identify the GABA-producing bacterial isolates. Total genomic DNA was extracted from the isolates using the genomic DNA extraction kit (Bioneer, Korea). Amplification of the 16S rRNA gene was performed using universal primer set 27F (5' AGAGTT TGATCMTGGCTCAG-3') and 1492R (5'-CGGTTACCTTGTTAC GACTT-3') [27]. The PCR was performed in 20- $\mu$ l reaction mixtures containing a premix (Bioneer) with $1 \mu$ l template DNA, $1 \mu \mathrm{l}$ of $5 \mu \mathrm{M}$ each primer, and $17 \mu \mathrm{l}$ distilled water. The cycle conditions for the 16S rRNA gene amplification were as follows: initial denaturation at $95^{\circ} \mathrm{C}$ for $5 \mathrm{~min}$; followed by 32 cycles at $95^{\circ} \mathrm{C}$ for $45 \mathrm{sec}, 48^{\circ} \mathrm{C}$ for $45 \mathrm{sec}$, and $72^{\circ} \mathrm{C}$ for $75 \mathrm{sec}$, and a final extension at $72^{\circ} \mathrm{C}$ for $5 \mathrm{~min}$. The PCR products were purified using the QIAquick PCR Purification Kit (QIAGEN, Germany), then sequenced and analyzed by comparing the consensus sequences in the GenBank database (http:/ / www.ncbi.nlm.nih.gov/genbank) using the basic local alignment search tool (BLAST) [28].

\section{Identification of Bacillus spp.}

Based on the 16S rRNA gene sequencing data and reference strains from GenBank, Bacillus strains were distinguished from each other preliminarily by the reference culture media of mannitol-egg yolk-polymyxine agar (MYPA, Difco, USA), polymyxin-egg-yolk-mannitol-bacillus agar (PEMBA, UK), and phenol red dextrose agar (PRDA, Oxoid). In addition, the characteristics of hemolysis and lecithinase for the B. cereus group were tested. The hemolytic zones formed were observed and classified based on lytic activities of red blood cells in the media around and under the colonies. The lecithinase activity was determined by pink colonies with opaque halos on the MYPA medium. The extracted DNA was subjected to PCR using the primer pair $\mathrm{BC} 1 / \mathrm{BC} 2 \mathrm{r}$ to classify as part of the B. cereus group [29]. B. cereus strains were distinguished from Bacillus thuringiensis strains by $\mathrm{PCR}$ with the following primer pairs targeting the gyrB gene: BT1/BT2r, BFW1/BCrevnew [30]. The following Bacillus exotoxin genes were also confirmed by the primer pairs ETF/ETR used to detect becT of enterotoxin T [31], and EntFM-F/EntFM-R [32] and ENTA/ENTB [33] were used to detect entFM of enterotoxin FM. Finally, the Bacillus isolates were confirmed by $\mathrm{PCR}$ with the $\mathrm{K} 3 / \mathrm{K} 5$ primer pair targeting the cry gene on the basis that $B$. cereus does not produce crystal toxin, whereas B. thuringiensis does [34]. B. cereus KCCM 1034 and B. thuringiensis KCTC 1094 type strains were used as a reference control for PCR. Microscopy observations were carried out to detect crystal proteins ( $\delta$-endotoxins) for the distinction of $B$. thuringiensis among the $B$. cereus group strains. The simple staining procedure with TB carbol-fuchsin ZN (BD BBL Difco) was used for staining the cells [35]. The crystal proteins were examined with an optical microscope (Optika, Italy).

\section{Identification of Staphylococcus spp.}

The first key coagulase test was carried out to divide Staphylococcus into two main groups: coagulase positive Staphylococci (CPS) and coagulase negative Staphylococci (CNS). Bacterial cultures of Staphylococci spp. were incubated at $37^{\circ} \mathrm{C}$ for $16 \mathrm{~h}$ in tryptic soy broth (TSB, Oxoid). The coagulase-positive organism caused the plasma to form a clot in the test tube whereas, the coagulasenegative organism did not [36]. Further, CPS and CNS were differentiated by biochemical test on mannitol salt agar (MSA, Oxoid). The production of yellow colonies due to the high salt content of media and fermentation of mannitol is regarded as a presumptive tool for the identification of CPS [37]. The PCR amplification was performed to identify Staphylococcus spp. for 
nuc gene target which CPS encoded while CNS did not, by using the pair of primers Sa1 and Sa2 [38]. The strains S. aureus ATCC 19095 and S. epidermis KCCM 40416 were used as positive and negative controls, respectively. Finally, 16S rRNA gene sequencing was done again to confirm the subspecies of Staphylococcus isolates using the universal primer set $27 \mathrm{~F}$ and $1492 \mathrm{R}$ as decribed above.

\section{GABA Production on Glutamate-Reinforced Medium}

The best GABA-producing strain would be chosen for further investigation of the maximum GABA accumulation under glutamate-reinforced conditions. Four desired conditions for strain cultivation for enhancing GABA levels were as follows: MRS containing $500 \mathrm{mM}$ MSG, incubated at $30^{\circ} \mathrm{C}$ for $72 \mathrm{~h}$; MRS containing $700 \mathrm{mM} \mathrm{MSG}, \mathrm{pH} 5,30^{\circ} \mathrm{C}$ for $72 \mathrm{~h}$; MRS containing $700 \mathrm{mM}$ MSG supplement with 2\% maltose and 3\% tryptone, $\mathrm{pH} 5$, incubated at $30^{\circ} \mathrm{C}$ for $72 \mathrm{~h}$; and MRS containing $400 \mathrm{mM}$ MSG with $3.5 \%$ glucose, $\mathrm{pH} 5$, incubated at $32^{\circ} \mathrm{C}$ for $48 \mathrm{~h} \mathrm{[18].} \mathrm{The}$ GABA content would be determined and compared with the basic culture condition of 500 mM MSG in MRS by HPLC as described above.

\section{Results and Discussion}

\section{Microbiological Analysis and Characteristics}

Viable cell counts in all samples were various from 0 to $10^{7} \mathrm{CFU} / \mathrm{ml}$. In the Korean fermented fish samples, the density of microorganisms was $1.94 \times 10^{7} \mathrm{CFU} / \mathrm{ml}$, whereas in the Vietnamese fermented fish samples, the maximum density was $5.17 \times 10^{5} \mathrm{CFU} / \mathrm{ml}$. This proportion was consistent with previous studies reporting an average mesophilic bacterial counts at $3.6 \times 10^{7}$ on PCA agar as well as a similar viable cell count of $10^{5}$ in fermented seafood products in Indonesia [39, 40]. Among them, 91 colonies of acid-producing bacteria were selected by the presence of yellow zones, and then they were classified in 9 groups (A-

Table 1. Characteristics of acid-producing bacteria isolated from Korean and Vietnamese fermented fish products.

\begin{tabular}{|c|c|c|c|c|c|c|c|c|c|}
\hline Characteristics & A & B & $\mathrm{C}$ & $\mathrm{D}$ & $\mathrm{E}$ & $\mathrm{F}$ & G & $\mathrm{H}$ & I \\
\hline Number of isolates & 11 & 15 & 4 & 6 & 17 & 4 & 4 & 16 & 14 \\
\hline Shape & Cocci & Cocci & Rod & Rod & Rod & Cocci & Cocci & Rod & Rod \\
\hline Gram stain & + & + & + & + & + & + & + & + & + \\
\hline Gas from D-glucose & $7 / 11$ & $9 / 15$ & + & + & $11 / 17$ & + & + & $12 / 16$ & + \\
\hline Catalase & - & - & - & - & - & + & + & + & + \\
\hline Fermentation type & Homo & Homo & Hetero & Homo & Homo & Hetero & Homo & Hetero & Homo \\
\hline Heat shock at $60^{\circ} \mathrm{C}, 15 \mathrm{~min}$ & $\mathrm{w}$ & $\mathrm{w}$ & $\mathrm{w}$ & $\mathrm{w}$ & $\mathrm{w}$ & + & + & + & + \\
\hline \multicolumn{10}{|l|}{ Growth at temperature $\left(\mathrm{T}^{\circ} \mathrm{C}\right)$} \\
\hline $10 \leq \mathrm{T} \leq 37$ & + & + & + & + & + & + & + & + & + \\
\hline \multicolumn{10}{|l|}{ Growth at $\mathrm{pH}$} \\
\hline 3 & - & $\mathrm{w}$ & - & $\mathrm{w}$ & - & + & - & + & - \\
\hline 5 & + & + & + & + & + & + & $\mathrm{w}$ & + & + \\
\hline 7 & + & + & + & + & + & + & + & + & + \\
\hline 8.5 & + & + & + & + & + & + & + & + & + \\
\hline 9 & $6 / 11$ & $\mathrm{w}$ & $\mathrm{w}$ & $\mathrm{w}$ & $16 / 17$ & - & $3 / 4$ & $13 / 16$ & $2 / 14$ \\
\hline \multicolumn{10}{|l|}{ Growth in $\mathrm{NaCl}(\%)$} \\
\hline 1 & + & + & + & + & + & + & + & + & + \\
\hline 3 & + & + & + & + & + & + & $1 / 4$ & + & + \\
\hline 6.5 & + & + & + & + & + & + & $3 / 4$ & + & + \\
\hline 10 & $2 / 12$ & $7 / 12$ & $2 / 4$ & - & $3 / 17$ & $3 / 4$ & + & + & + \\
\hline 15 & - & $2 / 12$ & $1 / 4$ & - & - & - & $1 / 4$ & $11 / 16$ & $8 / 14$ \\
\hline 20 & - & - & - & - & - & - & - & $10 / 16$ & $2 / 14$ \\
\hline
\end{tabular}

Gram stain: +, Gram-positive; -, Gram-negative. Gas from glucose: +, producing gas from glucose; -, no gas produced.

Catalase: +, producing hydrogen peroxide; -, no hydrogen peroxide produced. Homo, homofermentative; Hetero, heterofermentative

Growth: +, normal growth; w, low growth rate; -, no growth 
I) based on biochemical and physiological tests (Table 1). Gram staining revealed $37 \%$ with a coccoid shape and $63 \%$ with a rod shape, and homo- and hetero-fermentative properties were also identified in these strains. Furthermore, more than $75 \%$ of the isolates could ferment glucose and produce $\mathrm{CO}_{2}$, and 29 strains grew well in $10 \% \mathrm{NaCl}$, while 23 stains could tolerate $15 \% \mathrm{NaCl}$ and 12 strains could tolerate up to $20 \% \mathrm{NaCl}$. Those salt-tolerant strains belonged to groups B (3 strains), G (1 strain), H (11 strains), and I (8 strains). All of these strains were isolated from Vietnamese fish products, except for two strains from Korean jeotgal, suggesting that mostly halophilic strains were present in Vietnamese fish products. The fact that $31 \%$ of strains tolerated a high-salt environment (10-20\%) throughout the fermentation of fish sauces revealed that these strains might play an active role in the fermentation process of fish sauces in Vietnam. This was in agreement with a previous study reporting that halophilic LAB were dominant at the final stage of fish sauce fermentation when color, aroma, and flavor were fully developed [41]. This has led to a prediction that halophilic LAB could play a significant role in the characteristics of fish sauces.

\section{Qualitative and Quantitative Analyses of GABA Production by TLC and HPLC}

Next, the 91 isolates were tested for their GABAproducing ability on TLC plates. Diluted GABA standards were used as a positive control, and MSG was used as negative control. Among the 91 acid-producing isolates, 27 $(30 \%)$ showed GABA spots on the TLC plates (Fig. 1). This was higher than the detection ratio of 10 strains in the 53 total strains isolated from traditional fermented foods of Ishikawa Prefecture in Japan (19\%), and also much higher than 12 of the 130 strains (9\%) that were isolated from Myanmar fishery products fermented with boiled rice [27, 42].

The GABA-production by 27 isolates were then quantitatively confirmed by HPLC. According to the gradient elution experimental results, the HPLC GABA standard curve was presented as $Y=0.2707 \mathrm{X}+66.449$ with a linear relationship $\left(R^{2}=0.982\right)$. HPLC chromatograms of the GABA standard solution and GABA produced by isolates were obtained with a retention time at $33.06 \mathrm{~min}$. All 27 GABA-producing isolates that produced GABA at various concentrations are indicated in Table 2.

All 27 isolates produced GABA at various concentrations in the range of 5 to $454 \mathrm{mM}$. In fish sauces, GABA was produced at concentrations of 10 to $435 \mathrm{mM}$, where the highest producer was by the isolate LA51 from Korean jeotgal. In shrimp pastes, GABA reached the highest concentration of $454 \mathrm{mM}$, where isolate LA43 was considered as the best producer. The GABA level produced in anchovy pastes was lowest at 18 to $65 \mathrm{mM}$. In general, isolates from Korean fermented fish products could produce GABA much more than those from Vietnam in the range of $45-454 \mathrm{mM}$, while the concentration of GABA in fermented fish products from Vietnam ranged from 5-366 $\mathrm{mM}$. The highest producers of GABA in Vietnamese and Korean fermented fish products belonged to isolate LH2134 in the Vietnamese fish sauce nиос mam and isolate LA43 in the Korean shrimp paste jeotgal, respectively.

\section{Genetic Analysis of GABA-Producing Microorganisms}

To identify the species, all isolates were subjected to comparative $16 \mathrm{~S}$ rRNA gene sequencing analysis using the BLAST search program at the NCBI website. The $16 \mathrm{~S}$ rRNA

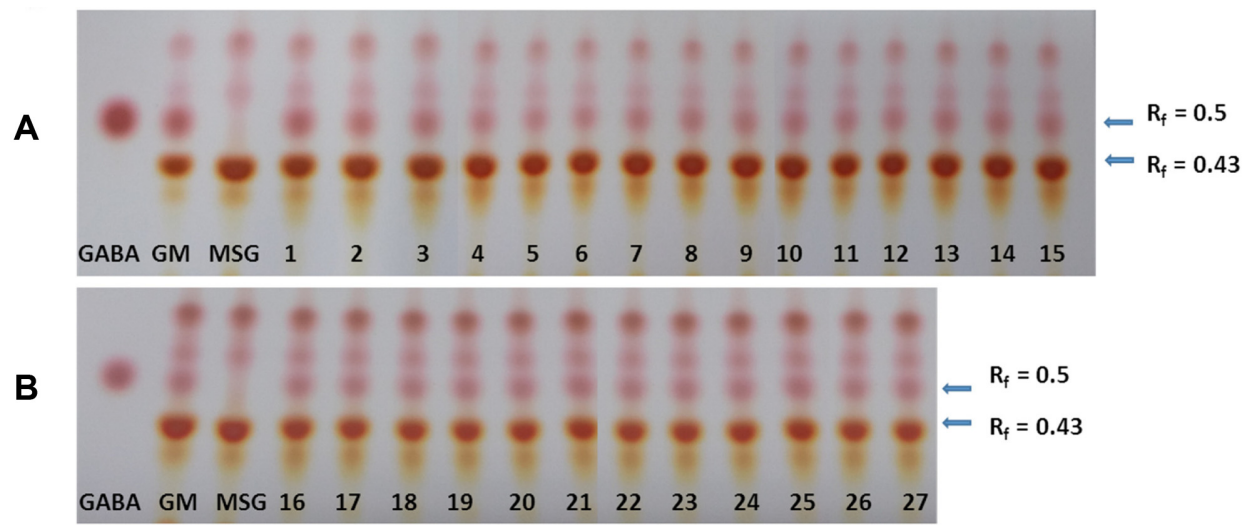

Fig. 1. Thin layer chromatogram of GABA production.

Lane GABA, GABA standard at concentration of $2 \mathrm{mg} / \mathrm{ml}$; Lane GM, mixture of GABA and MSG; Lane MSG, monosodium glutamate in MRS (negative control) at concentrations of 1\%; 1A, lanes 1-15; 1B, lanes 16-27 presented bacterial isolates cultured in MRS medium with 1\% MSG. 
Table 2. Production of GABA in MRS media containing 500 mM MSG.

\begin{tabular}{|c|c|c|c|c|}
\hline No. & Groups & $\begin{array}{l}\text { Isolate } \\
\text { names }\end{array}$ & $\begin{array}{c}\text { GABA } \\
\text { Production } \\
(\mathrm{mM})\end{array}$ & Source isolated (sample maker) \\
\hline 1 & A & LA43 & 454.18 & Salted shrimp sauce (OS, Korea) \\
\hline 2 & & LA51 & 434.75 & Sand lance sauce $(\mathrm{CH}$, Korea) \\
\hline 3 & & LA49 & 421.59 & Salted shrimp sauce (OS, Korea) \\
\hline 4 & & LA45 & 405.54 & Salted shrimp sauce (OS, Korea) \\
\hline 5 & & LA47 & 336.32 & Salted shrimp sauce (OS, Korea) \\
\hline 6 & & LA44 & 285.55 & Salted shrimp sauce (OS, Korea) \\
\hline 7 & & LA46 & 256.22 & Salted shrimp sauce (OS, Korea) \\
\hline 8 & & LA52 & 245.19 & Sand lance sauce $(\mathrm{CH}$, Korea) \\
\hline 9 & & LA42 & 196.42 & Salted shrimp sauce (OS, Korea) \\
\hline 10 & & LA410 & 44.95 & Salted shrimp sauce (OS, Korea) \\
\hline 11 & B & LB48 & 224.18 & Salted shrimp sauce (OS, Korea) \\
\hline 12 & & LB41 & 141.56 & Salted shrimp sauce (OS, Korea) \\
\hline 13 & & LB18 & 136.94 & Fish sauce (SM, Vietnam) \\
\hline 14 & $\mathrm{C}$ & LC129 & 180.97 & Fish sauce (SM, Vietnam) \\
\hline 15 & $\mathbf{F}$ & LF27 & 101.58 & Fish sauce (NP, Vietnam) \\
\hline 16 & G & LG46 & 89.96 & Fish sauce (NN, Vietnam) \\
\hline 17 & & LG532 & 64.82 & Fish paste (MNX, Vietnam) \\
\hline 18 & & LG238 & 40.57 & Fish paste (MNX, Vietnam) \\
\hline 19 & & LG230 & 18.48 & Fish sauce (NN, Vietnam) \\
\hline 20 & $\mathbf{H}$ & LH2134 & 366.02 & Fish sauce (Barona, Vietnam) \\
\hline 21 & & LH2241 & 92.87 & Fish sauce (KH, Vietnam) \\
\hline 22 & & LH139 & 46.36 & Fish sauce (NP, Vietnam) \\
\hline 23 & & LH510 & 27.23 & Fish sauce (CM, Vietnam) \\
\hline 24 & I & LI813 & 49.83 & Anchovy paste (TP, Vietnam) \\
\hline 25 & & LI915 & 34.77 & Sour shrimp paste (NL, Vietnam) \\
\hline 26 & & LI140 & 10.62 & Fish sauce (NP, Vietnam) \\
\hline 27 & & LI324 & 5.4 & Sour shrimp paste (SM, Vietnam) \\
\hline
\end{tabular}

gene sequencing of all 27 isolates were identified from 99 to $100 \%$ identity. LAB, as the dominant species, included 14 isolates: 12 Lactococcus lactis, one E. faecium, and one Lactococcus pentosus. The second group identified belonged to the $B$. cereus group with eight strains. Seven strains were identified as $B$. thuringiensis and one strain as B. cereus. Lastly, gene sequencing of five isolates identified as Staphylococcus spp. included two isolates identified as Staphylococcus pasteuri and Staphylococcus piscifermentans, respectively. All the 27 isolates that were identified are shown with their sequence identity in Table 3. LAB was the dominant species as indicated by the 14 isolates that were identified, in which 12 strains belonged to Lactococcus lactis spp. with $100 \%$ sequence identity to type strains. The remaining isolates of $\mathrm{LAB}$ belonged to E. faecium and another one was identified as L. pentosus. The second dominant species belonged to the B. cereus group with 99$100 \%$ sequence identity to type strains. Gene sequencing of the five isolates identified them as Staphylococcus spp. and included two S. hominis, one S. carnosus, one S. pasteuri, and one $S$. piscifermentans.

Moreover, PCR using the species-specific primer pair LlaR and LlaF was carried out to confirm the 12 strains of $\mathrm{LAB}$. The result revealed that all 12 strains belonged to the genus Lactococcus, and the phylogenic analyses of L. lactis LA43 and B. thuringiensis LH2134 are shown in Fig. 2. Identification by an API kit also obtained the accurate identification result of $99.9 \%$ for B. thuringiensis LH2134 and $99.1 \%$ for Lactococcus lactis LA43 (data not shown).

\section{Identification of Bacillus spp.}

Among the eight strains of the $B$. cereus group, seven isolates were $B$. thuringiensis strains and one isolate was identified as B. cereus. These Bacillus strains were confirmed by PCR using the primer pairs following BCrevnew/BCFW1, $\mathrm{BT} 1 / \mathrm{BT} 2 \mathrm{r}$, and $\mathrm{K} 3 / \mathrm{K} 5$ targeting the cry gene because the crystal toxin is only expressed by B.thuringiensis. The results showed that LH2134, LH2241, LH139, LI140, LI915, LI324, and LI813 harbor the cry gene, except LH510, which was identified as a B.cereus strain without the cry gene (Fig. 3). Among them, strains LI324 and LH510 contained the bceT gene, which is expressed for enterotoxin production and were recognized by the ETR/ETF primer pair (Table 4). Results of the PCR using species-specific primers are presented in Table 6. Finally, seven selected strains of $B$. thuringiensis were identified based on the presence of the crystal toxin protein, and these results are presented in Fig. 4.

The results obtained from Vietnamese fish sauces that revealed mostly species of $B$. cereus group in this study were in accordance with results from a previous study of nam pla (traditional Thai fish sauce) which showed all isolates belonged to Bacillus species such as Bacillus cereus, B. circulans, B. licheniformis, B. megaterium, B. pumilus, and B. subtilis [43]. Furthermore, the samples of patis liquid collected after one month of fermentation from the Rufina Co., Malabon, the Philippines, showed that they contained single strains of B. pumilus and another strains of Micrococcus colpogenes, M. varians, and Candida clausenii. The patis residue contained single strains of B. coagulans, B. licheniformis, and Achromobacter thalassius [43]. Similarly, the samples of 
Table 3. Identification of the bacterial 16S rRNA gene sequences obtained from fermented fish samples.

\begin{tabular}{|c|c|c|c|c|c|c|}
\hline No. & Group & $\begin{array}{l}\text { Isolate } \\
\text { name }\end{array}$ & Phylotype & Closest sequence & $\begin{array}{c}\text { Identity } \\
\%\end{array}$ & $\begin{array}{l}\text { Accession } \\
\text { Number }\end{array}$ \\
\hline 1 & \multirow{10}{*}{ A } & LA42 & Lactococcus lactis sp. & Lactococcus lactis subsp. lactis KLab14 & 100 & KM485587 \\
\hline 2 & & LA43 & Lactococcus lactis sp. & Lactococcus lactis subsp. lactis RCP438 & 100 & KT260650 \\
\hline 3 & & LA44 & Lactococcus lactis sp. & Lactococcus lactis RCB1015 & 100 & KT261227 \\
\hline 4 & & LA45 & Lactococcus lactis sp. & Lactococcus lactis HP16 & 100 & KX586694 \\
\hline 5 & & LA46 & Lactococcus lactis sp. & Lactococcus lactis subsp. lactis JC10 & 100 & GU936959 \\
\hline 6 & & LA47 & Lactococcus lactis sp. & Lactococcus lactis Lc1 & 100 & MG825732 \\
\hline 7 & & LA49 & Lactococcus lactis sp. & Lactococcus lactis Sourdough C6 & 100 & MG754583 \\
\hline 8 & & LA410 & Lactococcus lactis sp. & Lactococcus lactis subsp. lactis Lc2 & 100 & MG825730 \\
\hline 9 & & LA51 & Lactococcus lactis sp. & Lactococcus lactis subsp. lactis Lc5 & 100 & MG825736 \\
\hline 10 & & LA52 & Lactococcus lactis sp. & Lactococcus lactis subsp. cremoris Lc4 & 100 & MG825739 \\
\hline 11 & \multirow{3}{*}{ B } & LB41 & Lactococcus lactis sp. & Lactococcus lactis BGAL3-40 & 100 & HE646382 \\
\hline 12 & & LB48 & Lactococcus lactis sp. & Lactococcus lactis subsp. lactis G50 & 100 & СР025500 \\
\hline 13 & & LB18 & Enterococcus sp. & Enterococcus faecium $\mathrm{PH}-1$ & 99 & AY723748 \\
\hline 14 & $\mathrm{C}$ & LC129 & Lactobacillus sp. & Lactobacillus pentosus SY124 & 100 & LC041124 \\
\hline 15 & F & LF27 & Staphylococcus sp. & Staphylococcus piscifermentans NCTC13836 & 99 & LT906447 \\
\hline 16 & \multirow{4}{*}{ G } & LG230 & Staphylococcus sp. & Staphylococcus pasteuri $\mathrm{H} 23$ & 100 & KU922334 \\
\hline 17 & & LG238 & Staphylococcus sp. & Staphylococcus carnosus HSP-S16 & 99 & MG669651 \\
\hline 18 & & LG46 & Staphylococcus sp. & Staphylococcus hominis BC26 & 99 & KF254627 \\
\hline 19 & & LG532 & Staphylococcus sp. & Staphylococcus hominis SubaKolSh24 & 99 & JX625996 \\
\hline 20 & \multirow{4}{*}{$\mathrm{H}$} & LH510 & Bacillus cereus group & Bacillus cereus M13 & 99 & СР016360 \\
\hline 21 & & LH139 & Bacillus cereus group & Bacillus thuringiensis YJB4 & 99 & KU291379 \\
\hline 22 & & LH2134 & Bacillus cereus group & Bacillus thuringiensis DItb1006-3 & 100 & KT835652 \\
\hline 23 & & LH2241 & Bacillus cereus group & Bacillus thuringiensis SDY-3 & 99 & JX015365 \\
\hline 24 & \multirow{4}{*}{ I } & LI140 & Bacillus cereus group & Bacillus thuringiensis serovar galleriae HD-29 & 99 & СР010089 \\
\hline 25 & & LI324 & Bacillus cereus group & Bacillus thuringiensis YBT-1518 & 99 & СР005935 \\
\hline 26 & & LI915 & Bacillus cereus group & Bacillus thuringiensisVKK-LO & 100 & KT714050 \\
\hline 27 & & LI813 & Bacillus cereus group & Bacillus thuringiensis c25 & 100 & СР022345 \\
\hline
\end{tabular}

koami and ounago were prepared from shrimp (Mysis spp.) and a small unidentified fish in Japan contained one strain for B. cereus and B. sphaericus, four strains for B. megaterium, and one strain for Penicillium notatum. Particularly, B. thuringiensis was not detected, neither were yeasts, fungi, and obligate anaerobic bacteria [43]. However, in this study, the isolates that were identified were mainly strains of $B$. thuringiensis; therefore, our study is the first to report that strains of $B$. thuringiensis are distributed in Vietnamese fermented fish products.

The genetic analysis revealed $14 \mathrm{LAB}$, seven Bacillus thuringiensis, one B. cereus, and five Staphylococcus spp. strains. The results indicated that species of LAB predominated as the microflora for fermenting raw fish under high salt conditions. This could explain why LAB play an important role in preserving and processing a variety of fermented foods. Lactic acid fermentation would help to prevent the growth of foodborne microorganisms. Acid produced by the fermentation could also change the flavor of the raw materials and improve the nutritional values [44].

The presence of Bacillus species, spore-forming bacteria in the completely fermented products, reflected the strong resistant nature of these bacterial species. Bacillus spp. might be detected only in fermented fish products of Vietnam as a tropical country. While Bacillus are warmthloving bacteria with an optimum growth temperature of $30-45^{\circ} \mathrm{C}$, some species can even grow at temperatures of $65^{\circ} \mathrm{C}$ [45]. Moreover, some previous studies revealed that 


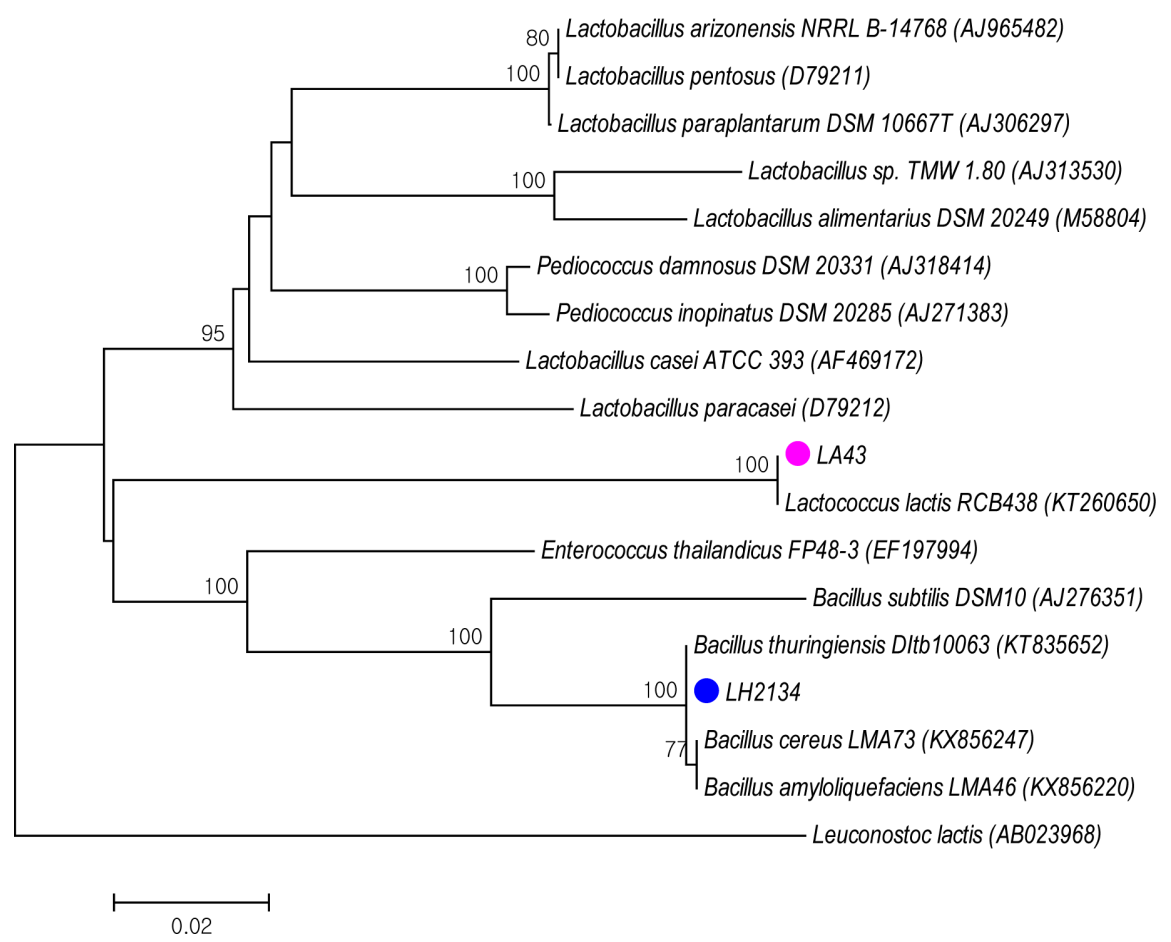

Fig. 2. Neighbor-joining tree based on $16 \mathrm{~S}$ rRNA gene sequences of representative strains and the reference strains. Bootstrap values based on 100 replications are given at the nodes.

fermented fish supernatants often contained large amounts of microorganisms, where millions of cells could be found in $1 \mathrm{ml}$ of the sauce extracts. The bacteria found in a ninemonth-old fish sauce included LAB, Micrococcus, Spirilum, Proteus, Leuconostoc, Clostridium, and mold, and approximately $70 \%$ of the bacterial isolates were halophiles of Bacillus types [46].

Despite $B$. thuringiensis being a unique bacterium in that it shared common traits with a number of chemical compounds

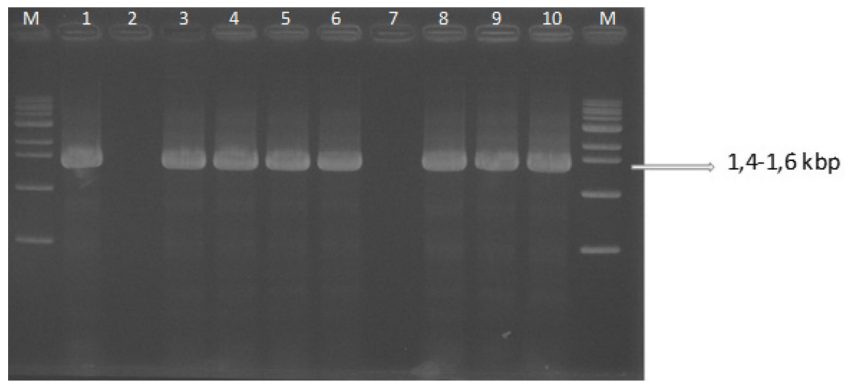

Fig. 3. PCR amplification of the cry gene from isolates performed with the primer pair $\mathrm{K} 3 / \mathrm{K} 5$.

Lane 1: (+) control Bacillus thuringiensis KCTC 1094; lane 2: (-) control Bacillus cereus KCCM 1034; Lane 3-10: isolates D2134, E2241, J139, A140, G510, C915, B324, and C813. that were used commercially to control insects, it is important for agriculture and public health. Importantly, B. thuringiensis is safe for humans and is the most widely used environmentally compatible biopesticide worldwide [47]. Therefore, the discovery of B. thuringiensis strains in this study may be of interest for isolating GABA-producing strains. The appearance of Staphylococcus spp. was accordant with the finding of Tanasupawat and ten new coagulasenegative Staphylococci strains isolated from fermented fish in Thailand [48]. However, the presence of LAB strains, B. thuringiensis and L. pentosus, which could be tolerant at high-salt environments $(15 \%)$ in the complete fermentation of fish sauces, suggests that these strains could play an active role in the fermentation process of fish sauces in Vietnam. Our result was also strongly supported by a previous study that reported L. pentosus strain S1 isolated from a Malaysian fermented fish product known as pekasam, which possessed probiotic potential and was safe for human consumption [49].

As shown in Table 5, it was interesting that the GABA yields by strains isolated from Korean fermented fish products were higher than those of strains from Vietnam. The best producer of GABA was found in shrimp paste from Korea, but not from fish sauce, which has been the 
Table 4. Differentiation of B. cereus and B. thuringiensis strains using $16 \mathrm{~S}$ rRNA gene and specific-gene targeted PCR primers.

\begin{tabular}{|c|c|c|c|c|c|c|c|c|}
\hline \multirow{2}{*}{$\begin{array}{l}\text { Isolate } \\
\text { name }\end{array}$} & \multirow{2}{*}{$\begin{array}{c}\text { 16s rRNA gene } \\
27 \mathrm{~F} / 1492 \mathrm{R}\end{array}$} & \multicolumn{3}{|c|}{ gyrB gene } & \multirow{2}{*}{$\begin{array}{c}\text { cry gene } \\
\mathrm{K} 3 / \mathrm{K} 5\end{array}$} & \multicolumn{2}{|c|}{ entFM gene } & \multirow{2}{*}{$\begin{array}{l}b c e T \text { gene } \\
\text { ETR/ETF }\end{array}$} \\
\hline & & $\mathrm{BC} 1 / \mathrm{BC} 2 \mathrm{r}$ & BT1/BT2r & BCRevnew/BCFw1 & & ENTA/ENTB & EntFM-F/EntFM-R & \\
\hline LH2134 & Bacilllus sp. & + & + & + & + & - & - & - \\
\hline LH2241 & Bacilllus sp. & + & + & + & + & - & - & + \\
\hline LH139 & Bacilllus sp. & + & + & + & + & - & - & - \\
\hline LI140 & Bacilllus sp. & + & + & + & + & - & - & - \\
\hline LH510 & Bacilllus sp. & + & - & - & - & - & - & + \\
\hline LI915 & Bacilllus sp. & + & + & + & + & - & - & - \\
\hline LI324 & Bacilllus sp. & + & + & + & + & - & - & - \\
\hline LI813 & Bacilllus sp. & + & + & + & + & - & - & - \\
\hline
\end{tabular}

more popular food item in Korea. This study was the first to reveal that the strain L. lactis LA43 produced GABA at the highest amount $(454 \mathrm{mM})$ among those strains isolated from the shrimp paste (jeotgal) from Korea.

The fact that fermented fish products in Asian countries may contain 20 and up to $30 \% \mathrm{NaCl}$ suggests that they could contain a distinct halophilic microflora. The detection of L. pentosus with a high tolerance to $\mathrm{NaCl}(15 \%)$ in this study suggested it was a new moderate halophilic LAB, which could not be isolated from the population of halophilic microorganisms in ikashiokara, a fermented fish product containing $20 \% \mathrm{NaCl}$ [43]. Furthermore, in this study, we have found that among the GABA-producing strains, the strain B. thuringiensis LH2134 isolated from nuoc mam of the Barona brand from Vietnam produced GABA at a concentration of $366 \mathrm{mM}$, which was higher than the amount of GABA produced by Weissella hellenica SB105 strain isolated from ika-kurozukuri salted squid with ink and liver in Japan in a previous study [42]. The W. hellenica SB105 strain produced GABA at the highest concentration of $7.69 \mathrm{mg} / \mathrm{ml}$ (approximately $74.57 \mathrm{mM}$ ) among the LAB strains isolated from traditional fermented foods of Ishikawa Prefecture, Japan. However, in a previous study, the authors were unable to detect any strains that

Table 5. Comparison between GABA-producing strains isolated from the fermented fish products in Vietnam and Korea.

\begin{tabular}{|c|c|c|c|c|c|}
\hline \multirow{2}{*}{$\begin{array}{l}\text { Fermented fish } \\
\text { products }\end{array}$} & \multirow[t]{2}{*}{ Ingredients } & \multirow{2}{*}{$\begin{array}{l}\text { Number of } \\
\text { samples }\end{array}$} & \multirow{2}{*}{$\begin{array}{l}\text { Species identification } \\
\text { (number of isolates) }\end{array}$} & \multicolumn{2}{|c|}{$\begin{array}{l}\text { GABA production } \\
\text { yield }(\mathrm{mM})\end{array}$} \\
\hline & & & & Vietnam samples & Korea samples \\
\hline \multirow{8}{*}{ Fish sauces } & \multirow{8}{*}{$\begin{array}{l}\text { Anchovy, sand lance } \\
(75-85 \%) \text {, salt, water, with } \\
\text { or without preservatives, } \\
\text { stabilizers, flavor, degrees } \\
\text { of protein }(10-40 \%)\end{array}$} & \multirow{8}{*}{29} & Bacillus thuringiensis (4) & \multirow{8}{*}{$(10.62-366.02)$} & \multirow{8}{*}{$(245.19-434.75)$} \\
\hline & & & Lactococcus Lactis (2) & & \\
\hline & & & Enterococcus faecium (1) & & \\
\hline & & & Lactobacillus pentosus (1) & & \\
\hline & & & Staphylococcus pasteuri (1) & & \\
\hline & & & Staphylococcus piscifermentans (1) & & \\
\hline & & & Staphylococcus hominis (1) & & \\
\hline & & & Bacillus cereus (1) & & \\
\hline \multirow{3}{*}{ Shrimp pastes } & \multirow{3}{*}{ Small shrimp, salt, spices } & \multirow{3}{*}{7} & Bacillus thuringiensis (1) & \multirow{3}{*}{$(5.4-34.77)$} & \multirow{3}{*}{$(44.95-454.18)$} \\
\hline & & & Bacillus thuringiensis (1) & & \\
\hline & & & Lactococcus Lactis (10) & & \\
\hline \multirow{4}{*}{ Anchovy pastes } & \multirow{3}{*}{$\begin{array}{l}\text { Anchovy , small mackerel, } \\
\text { salt, garlic, chili, sugar }\end{array}$} & & Bacillus thuringiensis (1) & \multirow{3}{*}{$(18.48-64.82)$} & \multirow{3}{*}{ ND } \\
\hline & & 5 & Staphylococcus hominis (1) & & \\
\hline & & & Staphylococcus carnosus (1) & & \\
\hline & Total & 41 & 27 & $(5.4-366.02)$ & $(44.95-454.18)$ \\
\hline
\end{tabular}

ND; not detected 
Table 6. GABA production under glutamate-reinforced condition by Lactococcus lactis LA43.

\begin{tabular}{|c|c|c|c|c|c|c|c|c|c|}
\hline Medium & Nutrients & $\mathrm{pH}$ & $\begin{array}{l}\text { Temperature } \\
\left({ }^{\circ} \mathrm{C}\right)\end{array}$ & $\begin{array}{c}\text { Incubation } \\
\text { time } \\
\text { (h) }\end{array}$ & Condition & References & $\begin{array}{c}\log \\
\mathrm{CFU} / \mathrm{ml}\end{array}$ & $\begin{array}{c}\text { GABA } \\
\text { production } \\
\mathrm{mM}\end{array}$ & $\begin{array}{c}\text { GABA } \\
\text { conversion } \\
\text { yield }(\%)\end{array}$ \\
\hline B & $\mathrm{MRS}+700 \mathrm{mM}$ MSG & 5 & 30 & 72 & Anearobic & This study & $10.6 \pm 0.04$ & 684.54 & 97.79 \\
\hline $\mathrm{C}$ & $\begin{array}{l}\text { MRS }+700 \mathrm{mM} \text { MSG }+ \\
2 \% \text { Maltose }+3 \% \text { Tryptone }\end{array}$ & 5 & 30 & 72 & Anearobic & This study & $12.2 \pm 0.15$ & 695.97 & 99.42 \\
\hline $\mathrm{D}$ & $\begin{array}{l}\text { MRS + } 400 \mathrm{mM} \mathrm{MSG} \mathrm{+} \\
3.5 \% \text { Glucose }\end{array}$ & 5 & 32 & 48 & Anearobic & [18] & $9.4 \pm 0.13$ & 372.38 & 93.1 \\
\hline
\end{tabular}

produced GABA from ishiru (fish sauce) although it was sampled for experiments. GABA production from fermented shrimp paste and fish sauce was also previously reported [50] for some of the LAB species (not shown in detail) with maximum GABA levels of 0.011 and $0.106 \mathrm{mM}$, respectively. These amounts were very small in comparison with our study. In comparison with the GABA produced by the best producer L. paracasei NFRI 7415, which was isolated from a Japanese traditional fermented fish (funa-sushi), at a concentration of $302 \mathrm{mM}$, the strain L. lactis LA43 produced GABA at $454 \mathrm{mM}$ higher concentration, although it was cultured under non-optimal cultivation conditions, hence L. lactis LA43 could be considered a potential GABA producer under optimal conditions.

\section{GABA Production on Glutamate-Reinforced Medium}

After the identification and quantitative assay for the highest GABA producer, L. lactis LA43 was further examined for optimum GABA production under glutamate-reinforced conditions. GABA yields are shown in the Table 6. The optimal cultivation for GABA accumulation of L. lactis
LA43 was determined in MRS supplemented with $700 \mathrm{mM}$ MSG, $2 \%$ maltose, and 3\% tryptone at an initial pH of 5.0 and incubation temperature of $30^{\circ} \mathrm{C}$ for $72 \mathrm{~h}$, resulting in the production of $696 \mathrm{mM} \mathrm{GABA}$. It revealed also that supplements of carbon sources by maltose and tryptone contributed to cell growth, and the GABA production increased from 685 to $696 \mathrm{mM}$. Conditions such as medium composition and additives might significantly affect microbial GABA production. Most previous studies on the optimization of GABA production by LAB reported yeast extract as an optimal nitrogen source. However, it should be noted that the mixed nitrogen sources of tryptone and yeast extract have occasionally been reported to be optimal nitrogen sources for GABA production by LAB [51]. Diverse carbon sources have been previously optimized according to GABA-producing LAB strains, such as $1 \%$ glucose for L. buchneri MS, 4\% sucrose for L. sakei B2-16, and $3 \%$ sucrose for L. brevis 340G [19]. Maltose, as an optimal carbon source, and tryptone, as an ideal nitrogen source, in our study were determined to be the best nutrient supply for GABA production by L. lactis LA43,

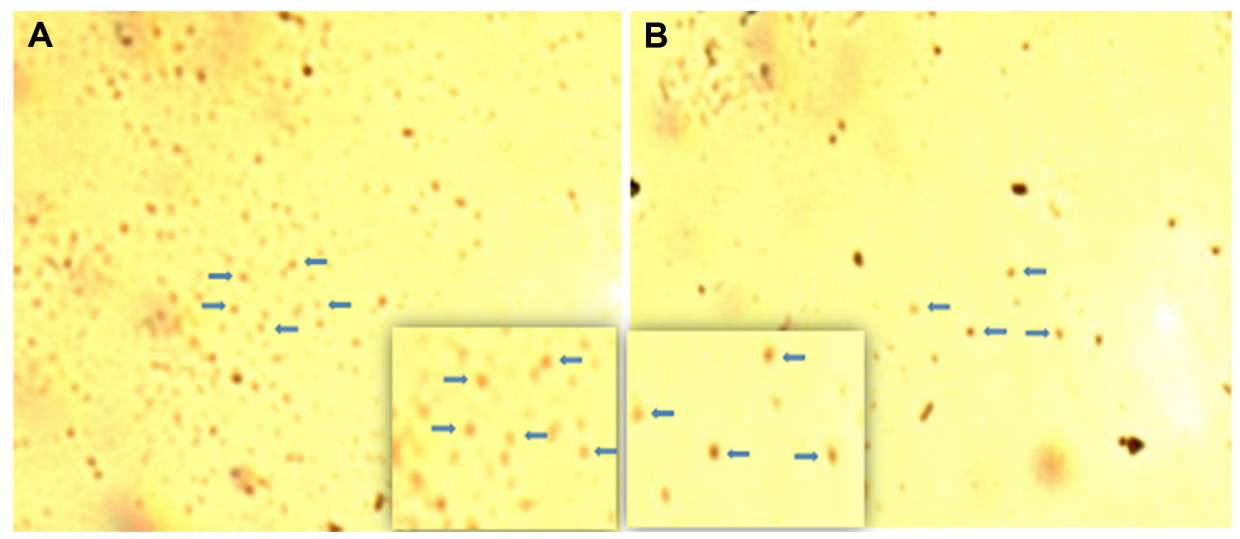

Fig. 4. Microscopy photographs of crystal proteins ( $\delta$-endotoxin): B. thuringiensis KCTC 1094 as a positive control (A), and B. thuringiensis LH2134 from fish sauce Barona of Vietnam (B).

The cells with $\delta$-endotoxin stained were shown clearly at the small boxes. 


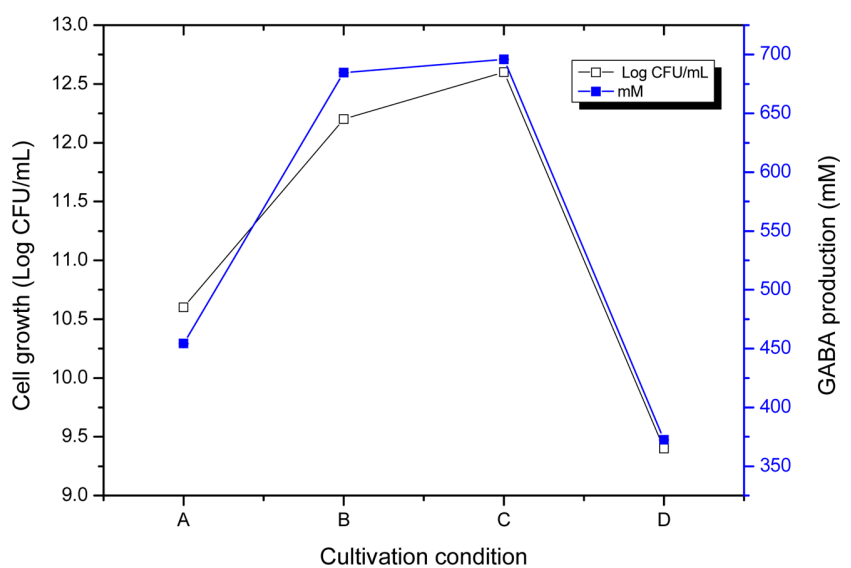

Fig. 5. Growth and GABA production of L. lactis LA43 in optimum culture conditions.

(A) MRS with $500 \mathrm{mM}$ MSG; (B) MRS with $700 \mathrm{mM}$ MSG; (C) MRS with $700 \mathrm{mM}$ MRS, $2 \%$ maltose, and 3\% tryptone; (D) MRS with $400 \mathrm{mM}$ MSG and $3.5 \%$ glucose.

which was in agreement with a previous study reporting $2 \%$ maltose and $3 \%$ tryptone for the optimum GABA production by L. brevis HYE1 [51].

Furthermore, another previous study reported that when the glutamate concentration in the culture medium was in excess of $500 \mathrm{mM}$, glutamate would inhibited the GABA production of the strain L. paracasei NFRI 7415, which was isolated from a Japanese traditional fermented fish (funasushi) at a maximum concentration of $302 \mathrm{mM}$ [15]. However, in our study, when the medium contained $700 \mathrm{mM}$ MSG, there was a higher accumulation of GABA at $685 \mathrm{mM}$ in comparison with medium that contained $500 \mathrm{mM}$ resulting in GABA yields of $454 \mathrm{mM}$, suggesting that the glutamate concentration in the medium was essential for GABA accumulation. Additionally, the optimum culture conditions for GABA production by L. buchneri MS from kimchi has been previously reported to be MRS broth containing $5 \%$ MSG, $1 \% \mathrm{NaCl}$, and $1 \%$ glucose, at an initial $\mathrm{pH}$ of 5.0 and incubation temperature of $30^{\circ} \mathrm{C}$ for $36 \mathrm{~h}$. Under these conditions, L. buchneri MS produced GABA at a concentration of $251 \mathrm{mM}$ with a $94 \%$ GABA conversion rate. In this study, L. lactis LA43 produced GABA at a concentration of $454 \mathrm{mM}$, and reached a conversion rate up to $99 \%$ in the optimum medium containing $700 \mathrm{mM} \mathrm{MSG}$, $2 \%$ maltose, and $3 \%$ tryptone. As the result, the strain L. lactis LA43 could be considered as a potential candidate for the optimum production of GABA under the optimal conditions.

\section{Acknowledgments}

This research was supported by the National Research Foundation of Korea(Grant\#2017R1D1A1B03033647).

\section{Conflict of Interest}

The authors have no financial conflict of interest to declare.

\section{References}

1. Yongsawatdigul J, Rodtong S, Raksakulthai N. 2007. Acceleration of Thai fish sauce fermentation using proteinases and bacterial starter cultures. J. Food Sci. 72: M382-390.

2. Park J-N, Watanabe T, Endoh K-I, Watanabe $\mathrm{K}$, Abe $\mathrm{H}$. 2002. Taste-active components in a Vietnamese fish sauce. Fish. Sci. 68: 913-920.

3. Nomura M, Nakajima I, Fujita Y, Kobayashi M, Kimoto H, Suzuki I, et al. 1999. Lactococcus lactis contains only one glutamate decarboxylase gene. Microbiology 145 (Pt 6): 13751380.

4. Diana M, Quílez J, Rafecas M. 2014. Gamma-aminobutyric acid as a bioactive compound in foods: a review. J. Funct. Foods 10: 407-420.

5. Kleinrok Z, Matuszek M, Jesipowicz J, Matuszek B, Opolski A, Radzikowski C. 1998. GABA content and GAD activity in colon tumors taken from patients with colon cancer or from xenografted human colon cancer cells growing as s.c. tumors in athymic nu/nu mice. J. Physiol. Pharmacol. 49: 303-310.

6. Braun M, Ramracheya R, Bengtsson M, Clark A, Walker JN, Johnson PR, et al. 2010. Gamma-aminobutyric acid (GABA) is an autocrine excitatory transmitter in human pancreatic beta-cells. Diabetes 59: 1694-1701.

7. Saikusa T, Horino T, Mori Y. 1994. Accumulation of $\gamma$ aminobutyric acid (Gaba) in the rice germ during water soaking. Biosci. Biotechnol. Biochem. 58: 2291-2292.

8. Shelp BJ, Bown AW, McLean MD. 1999. Metabolism and functions of gamma-aminobutyric acid. Trends Plant Sci. 4: 446-452.

9. Dhakal R, Bajpai VK, Baek K-H. 2012. Production of gaba ( $\gamma$ - Aminobutyric acid) by microorganisms: A review. Braz. J. Microbiol. 43: 1230-1241.

10. Li H, Gao D, Cao Y, Xu H. 2008. A high $\gamma$-aminobutyric acid-producing Lactobacillus brevis isolated from Chinese traditionalpaocai. Ann. Microbiol. 58: 649-653.

11. Huang J, Mei L, Sheng Q, Yao S, Lin D. 2007. Purification and characterization of glutamate decarboxylase of Lactobacillus brevis CGMCC 1306 isolated from fresh Milk*supported by the National Natural Science Foundation of China (No.30570411) and the Research Plan of Zhejiang Province, China. Chinese J. Chem. Eng. 15: 157-161. 
12. Park KB, Oh SH. 2007. Production of yogurt with enhanced levels of gamma-aminobutyric acid and valuable nutrients using lactic acid bacteria and germinated soybean extract. Bioresour. Technol. 98: 1675-1679.

13. Kim JY, Lee MY, Ji GE, Lee YS, Hwang KT. 2009. Production of gamma-aminobutyric acid in black raspberry juice during fermentation by Lactobacillus brevis GABA100. Int. J. Food. Microbiol. 130: 12-16.

14. Siragusa S, De Angelis M, Di Cagno R, Rizzello CG, Coda R, Gobbetti M. 2007. Synthesis of $\gamma$-aminobutyric acid by lactic acid bacteria isolated from a variety of Italian cheeses. Appl. Environ. Microbiol. 73: 7283-7290.

15. Komatsuzaki N, Shima J, Kawamoto S, Momose H, Kimura T. 2005. Production of $\gamma$-aminobutyric acid (GABA) by Lactobacillus paracasei isolated from traditional fermented foods. Food Microbiol. 22: 497-504.

16. Nomura M, Kimoto H, Someya Y, Furukawa S, Suzuki I. 1998. Production of $\gamma$-aminobutyric acid by cheese starters during cheese ripening. J. Dairy Sci. 81: 1486-1491.

17. La Anh N. 2015. Health-promoting microbes in traditional Vietnamese fermented foods: A review. Food Science and Human Wellness 4: 147-161.

18. Li H, Qiu T, Huang G, Cao Y. 2010. Production of gammaaminobutyric acid by Lactobacillus brevis NCL912 using fedbatch fermentation. Microb. Cell Fact. 9: 85.

19. Cho YR, Chang JY, Chang HC. 2007. Production of gammaaminobutyric acid (GABA) by Lactobacillus buchneri isolated from kimchi and its neuroprotective effect on neuronal cells. J. Microbiol. Biotechnol. 17: 104-109.

20. Lu X, Chen Z, Gu Z, Han Y. 2008. Isolation of $\gamma$-aminobutyric acid-producing bacteria and optimization of fermentative medium. Biochem. Eng. J. 41: 48-52.

21. Gibson LF, Khoury JT. 1986. Storage and survival of bacteria by ultra-freeze. Lett. Appl. Microbiol. 3: 127-129.

22. McDonald LC, McFeeters RF, Daeschel MA, Fleming HP. 1987. A differential medium for the enumeration of homofermentative and heterofermentative lactic acid bacteria. Appl. Environ. Microbiol. 53: 1382-1384.

23. De Man JC, Rogosa M, Elisabeth Sharpe M. 1960. A medium for the cultivation of Lactobacilli. J. Appl. Bact. 23: 130-135.

24. Holdiness MR. 1983. Chromatographic analysis of glutamic acid decarboxylase in biological samples. J. Chromatogr. B. 277: 1-24.

25. Kim M-J, Kim K-S. 2012. Isolation and identification of $\gamma$-aminobutyric acid (GABA)-producing lactic acid bacteria from Kimchi. J. Korean. Soc. Appl. Bi. 55: 777-785.

26. Rossetti V, Lombard A. 1996. Determination of glutamate decarboxylase by high-performance liquid chromatography. J. Chromatogr. B. Biomed. Appl. 681: 63-67.

27. Thwe SM, Kobayashi T, Luan T, Shirai T, Onodera M, Hamada-Sato N, et al. 2011. Isolation, characterization, and utilization of $\gamma$-aminobutyric acid (GABA)-producing lactic acid bacteria from Myanmar fishery products fermented with boiled rice. Fish. Sci. 77: 279-288.

28. Benson DA, Karsch-Mizrachi I, Lipman DJ, Ostell J, Rapp BA, Wheeler DL. 2002. GenBank. Nucleic Acids Res. 30: 17-20.

29. Yamada S, Ohashi E, Agata N, Venkateswaran K. 1999. Cloning and nucleotide sequence analysis of gyrB of Bacillus cereus, $B$. thuringiensis, B. mycoides, and B. anthracis and their application to the detection of B. cereus in rice. Appl. Environ. Microbiol. 65: 1483-1490.

30. Manzano M, Giusto C, Iacumin L, Cantoni C, Comi G. 2003. A molecular method to detect Bacillus cereus from a coffee concentrate sample used in industrial preparations. J. Appl. Microbiol. 95: 1361-1366.

31. Asano SI, Nukumizu Y, Bando H, lizuka T, Yamamoto T. 1997. Cloning of novel enterotoxin genes from Bacillus cereus and Bacillus thuringiensis. Appl. Environ. Microbiol. 63: 10541057.

32. Yang IC, Shih DY-C, Huang T-P, Huang Y-P, Wang J-Y, Pan T-M. 2005. Establishment of a novel multiplex PCR assay and detection of toxigenic strains of the species in the Bacillus cereus group. J. Food Protect. 68: 2123-2130.

33. Ghelardi E, Celandroni F, Salvetti S, Barsotti C, Baggiani A, Senesi S. 2002. Identification and characterization of toxigenic Bacillus cereus isolates responsible for two food-poisoning outbreaks. FEMS Microbiol. Lett. 208: 129-134.

34. Kuo WS, Chak KF. 1996. Identification of novel cry-type genes from Bacillus thuringiensis strains on the basis of restriction fragment length polymorphism of the PCRamplified DNA. Appl. Environ. Microbiol. 62: 1369-1377.

35. Guo S, Liu M, Peng D, Ji S, Wang P, Yu Z, et al. 2008. New strategy for isolating novel nematicidal crystal protein genes from Bacillus thuringiensis strain YBT-1518. Appl. Environ. Microbiol. 74: 6997-7001.

36. El Sanousi SM, B. Said KB, Elbager S, Awad A, Rodwan K, Eltom KH. 2015. A flow chart for the identification of Staphylococcus species. UK J. Vet. Med. Anim. Prod. 6: 93-97.

37. Lee YD, Moon BY, Park JH, Chang HI, Kim WJ. 2007. Expression of enterotoxin genes in Staphylococcus aureus isolates based on mRNA analysis. J. Microbiol. Biotechnol. 17: 461-467.

38. Brakstad OG, Aasbakk K, Maeland JA. 1992. Detection of Staphylococcus aureus by polymerase chain reaction amplification of the nuc gene. Eur. J. Clin. Microbiol. 30: 1654-1660.

39. Kobayashi T, Kajiwara M, Wahyuni M, Kitakado T, Hamada-Sato N, Imada C, et al. 2003. Isolation and characterization of halophilic lactic acid bacteria isolated from "terasi" shrimp paste: a traditional fermented seafood product in Indonesia. J. Gen. Appl. Microbiol. 49: 279-286.

40. Cho GS, Do HK. 2006. Isolation and identification of lactic acid bacteria isolated from a traditional jeotgal product in Korea. Ocean. Sci. J. 41: 113-119. 
41. Saisithi P. 1994. Traditional fermented fish: fish sauce production, pp. 111-131. In Martin AM (ed.), Fisheries Processing: Biotechnological applications, Ed. Springer US, Boston, MA, USA

42. Barla F, Koyanagi T, Tokuda N, Matsui H, Katayama T, Kumagai $\mathrm{H}$, et al. 2016. The $\gamma$-aminobutyric acid-producing ability under low $\mathrm{pH}$ conditions of lactic acid bacteria isolated from traditional fermented foods of Ishikawa Prefecture, Japan, with a strong ability to produce ACEinhibitory peptides. Biotechnol. Rep. 10: 105-110.

43. Crisan EV, Sands A. 1975. Microflora of four fermented fish sauces. Appl. Microbiol. 29: 106-108.

44. Savadogo A, Ouattara CAT, Traore AS. 2007. Potential of lactic acid bacteria in human nutrition. Food 1: 79-84.

45. Thwaite JE, Atkins HS. 2012. 21 - Bacillus: Anthrax; food poisoning A2 - Greenwood, David, pp. 237-244. In Barer M, Slack R, Irving W (eds.), Medical Microbiology (Eighteenth Edition), Ed. Churchill Livingstone, Edinburgh, UK.

46. Saisithi P, Kasemsarn RO, Liston J, Dollar Alexander M. 1966. Microbiology and chemistry of fermented fish. J. Food. Sci. 31: 105-110
47. Ibrahim MA, Griko N, Junker M, Bulla LA. 2010. Bacillus thuringiensis: a genomics and proteomics perspective. Bioeng. Bugs. 1: 31-50.

48. Tanasupawat S, Hashimoto Y, Ezaki T, Kozaki M, Komagata K. 1992. Staphylococcus piscifermentans sp. nov., from fermented fish in Thailand. Int. J. Syst. Bacteriol. 42: 577-581.

49. Ida Muryany MY, Ina Salwany MY, Ghazali AR, Hing HL, Nor Fadilah R. 2017. Identification and characterization of the lactic acid bacteria isolated from Malaysian fermented fish (Pekasam). Int. Food. Res. J. 24: 868-875.

50. Zareian M, Ebrahimpour A, Bakar FA, Mohamed AKS, Forghani B, Ab-Kadir MSB, et al. 2012. A glutamic acidproducing lactic acid bacteria isolated from Malaysian fermented foods. Int. J. Mol. Sci. 13: 5482-5497.

51. Lim HS, Cha IT, Roh SW, Shin HH, Seo MJ. 2017. Enhanced production of gamma-aminobutyric acid by optimizing culture conditions of Lactobacillus brevis HYE1 isolated from kimchi, a Korean fermented food. J. Microbiol. Biotechnol. 27: 450-459. 